NBER WORKING PAPER SERIES

\title{
DO DEVELOPING COUNTRIES LOSE FROM \\ THE MFA?
}

Irene Trela

John Whalley

Working Paper No. 2618

NATIONAL BUREAU OF ECONOMIC RESEARCH

1050 Massachusetts Avenue

Cambridge, MA 02138

June 1988

Earlier versions of this paper have been presented to seminars at Western Ontario and Guelph, and to a NBER Symposium on Applied General Equilibrium Analysis, held at Stanford, March 5-6, 1988. We are grateful to participants in all these sessions for comments. The research supported here is part of the NBER's research program in International Studies. Any opinions expressed are those of the authors and not those of the National Bureau of Economic Research. 
NBER Working Paper \#2618

June 1988

Do Developing Countries Lose from the MFA?

ABSTRACT

This paper provides estimates of both national and global welfare costs of bilateral quotas on textiles and apparel using an applied general equilibrium model which covers bilateral quotas on exports of textiles and apparel negotiated between three major developed importing countries (the US, Canada and the EEC) and 34 supplying developing countries under the provisions of the Multifibre Arrangement applying in mid-1980s (MFA III).

Results using 1986 data clearly show that the vast majority of developing countries gain from MFA removal, with some gaining proportionately more than others. This suggests that despite foregone rent transfers, developing countrles would recelve gains by eliminating the MFA. In the central variant analysis, all developing countries gain by eliminating tariff and MFA restrictions because, contrary to popular belief, the developing countries (including Hong Kong, South Korea and Taiwan) are relatively small compared to developed countrles even in apparel production. Rather than losing share to other developing countries under an MFA elimination, higher income developing countries (like other developing countries) gain market share at the expense of reduced developed country production.

Irene Trela Department of Economics Social Science Centre University of Western Ontario London, Ontario CANADA N6A 5C2
John Whalley

Department of Economics

Social Science Centre

University of Western Ontario

London, Ontario

CANADA N6A 5C2 


\section{Introduction}

Trade restrictions on textile and apparel ${ }^{1}$ exports by developing countries, under the Multi-Fibre arrangement (MFA) have been a topic of debate and dispute for many years. Developing countries frequently cite the MFA as one of the worst of the developed world's trade restrictions against them since it limits their market access and restricts their development. In contrast, it is of ten argued in developed countries that the transfer of quota rents to developing countries under the MFA more than of $f$ sets their loss of market access. This is given as a reason why developing countries generally support successive renegotiations of the MFA. There is also a heterogeneity of interest among developing countries which builds support for the MFA because higher income large quota receiving original MFA countries (Hong Kong, South Korea, and Taiwan) have a protected market niche against lower income developing countries with low quota.

To the present authors' knowledge, however, there is no currently available empirical work on any of these questions, and this paper is an attempt to partially fill the gap. It provides estimates of both national and global welfare costs of bilateral quotas on textiles and apparel using an applied general equilibrium model which covers bilateral quotas on exports of textiles and apparel negotiated between three major developed importing countries (the U.S., Canada, and the EEC) and 34 supplying developing countries under the provisions of the Multifibre Arrangement applying in mid-1980's (MFA III). 
Results using 1986 data clearly show that the vast majority of developing countries gain from MFA removal, with some gaining proportionately more than others. In aggregate they gain around $\$ 11$ billion. This suggests that despite foregone rent transfers, developing countries would receive gains by eliminating the MFA. Indeed, in the central variant analysis, all developing countries gain by eliminating the MFA. This is because, contrary to popular belief, the developing countries (including Hong Kong, South Korea, and Taiwan) are relatively small compared to developed countries even in apparel production. Thus rather than losing share to other developing countries under an MFA elimination, higher income developing countries (like other developing countries) gain market share at the expense of reduced developed country production. Results also suggest annual global gains from elimination of quotas and tariffs of around $\$ 17$ billion. Gains to the U.s. and EEC are around $\$ 3$ billion each, considerably lower than existing partial equilibrium estimates for reasons which are discussed in the text.

Sensitivity analyses suggest that a number of model features, including the treatment of relative countiy size and assumptions made in estimating production costs in individual developing countries are important for results, but the main themes of results are preserved. 


\section{A General Equilibrium Model of Global Irade in Textiles and Apparel}

Since 1974, imports of textiles and apparel by a number of major developed countries, including the U.S., Canada and the EEC, have been regulated through a series of international agreements among major exporting and importing countries, commonly known as the Multi-fibre Arrangements (MFAs) (of which there have now been four). ${ }^{3}$ These have produced a series of discriminatory bilateral quotas that now restrict exports by most lower cost developing countries to the major developed countries. 4

Under these agreements, licenses to export are issued to exporting countries, who then allocate them to firms within their country. These quotas restrict trade by limiting imports, and also further distort the pattern of trade because of their bilateral nature. Since the quotas are specified in physical terms, they also have the effect of encouraging upgrading of quality by exporters. Thus, protected producers in importing countries tend to produce lower quality items since the relative price of these increase in the protected domestic market.

The general equilibrium model we use to analyze the effects of these arrangements covers three major developed country importers, the U.S., Canada, and the EEC, thirty-four developing country exporters, 5 fourteen specific textile and apparel product categories, and one composite other good. ${ }^{6}$ The fourteen product categories reflect the constraints implied by generating a cross country data set covering trade under the different MFA quota categories used by the major importing countries (the U.S., Canada, and the EEC) ${ }^{7}$.

In the model, all developed countries are treated as net importers of textiles and apparel (and exporters of the other good), while all developing countries are modelled as exporters of textiles and apparel (and importers of the other good). Trade in textiles and apparel among developing countries 
does not take place in the model; otherwise differences in supply prices between these countries would be arbitraged away. Interdeveloped country trade is quota (although not tariff) free. Thus, the model captures trade diversion effects between developed countries due to their joint bilateral quotas on exports by developing countries. Domestic prices in the various developed countries therefore depend on the quota policies of all developed countries.

We also make calculations of the impacts of quotas using a version of the model where only one developed country (the U.S.), and the 34 developing countries are considered. In this model variant, we illustrate how the assumptions made on country size affect results when evaluating the effects of quotas (and rent transfers).

The model is calibrated to a 1986 multi-country microconsistent data set involving production, consumption, and trade in fourteen major textile and apparel product categories and one other good (residual GDP) for each of the thirty-seven countries captured. Data are also used on supply prices by product by country, and estimates of key elasticity parameters.

The data used is not free of problems. For example, while there is some (albeit limited) quota price data for Hong Kong, there is little direct information on supply prices for other supplying countries, and an indirect method, related to that recently used by Hamilton (1988), has to be employed. Also, because of incompatibilities among the various quota categories used in the major developed country MFA participants (the U.S., Canada, and the EEC), capturing effects of quotas on interdeveloped country trade in textiles and apparel is difficult. 
The model structure used is, in part, motivated by weaknesses of existing studies of the welfare costs of these bilateral quotas for individual developed countries, which are typically based on the partial equilibrium assumptions that the importing country (e.g. the U.S.) is a small open price-taking economy, and that full rent transfer to exporting countries occurs (see Jenkins (1980), Morkre and Tarr (1980), Morkre (1984), Siberston (1984), Greenaway (1986), Hufbauer et al. (1986) and Cline (1987)).

Assumed country size makes a substantial difference to the analyses since, in the extreme case where the importing country is large, no rent transfer occurs. Also, in assuming perfectly elastic supply functions partial equilibrium studies tend to overestimate the costs of textile restrictions to importing countries. In addition, these studies do not take into account the added costs to importing countries which arise from not purchasing from the lowest cost source of supply due to the bilateralism in the quotas. They concentrate either on single supplying country situations, or average supply prices across countries and then conduct single supplier analysis. Furthermore, these studies do not capture production substitution effects in exporting countries between various quota restricted and unrestricted categories. Finally, the welfare costs of trade restrictions used in any one developed country depend on the severity of restrictions in other developed countries, since interdeveloped country trade is quota (but not tariff) free, and these effects are not captured in existing work.

The model used here is free of these weaknesses. The relative size of developed to developing countries reflects differences in GDP, and so full rent transfer as in the small economy case, does not occur. Costs of bilateralism reflecting imports from higher cost suppliers are captured, as are Inter-category production substitution effects, and interdeveloped country 
trade. It also provides a vehicle for estimating the effects of textile restrictions on developing countries, something that has yet to be done in the literature.

\section{a) Level of Aggregation in the Model}

The fourteen textile and apparel products in the model involve seven restricted and seven comparable unrestricted products. The fourteen-cummodity level of aggregation used is shown in Table 1.

This approach is employed because despite the MFA, significant volumes of trade in textiles and apparel take place in unrestricted quota categories. If products in unrestricted categories are treated as perfect substitutes for quota restricted products, then in a competitive model countries would substitute costlessiy into products not subject to quota. In practice, there are differences below the level of aggregation in Table 1 in what is restricted and what is unrestricted and, in addition, a number of bilateral agreements include provisions for consultations that can result in unrestricted products being brought under restraint. An assumption of qualitative differences between comparable restricted and unrestricted categories is the way we treat this difficulty in the model.

\section{b) Production}

Each of thirty-seven countries in the model, including the three developed countries, is assumed to have a nested constant elasticity of transformation production possibilities frontier involving the fourteen textile products ${ }^{8}$ and one composite other good, 


\section{Table 1}

Commodity Asgregation For Textiles and Apparel Used in The Hodell

1. Winter outerwear; rainwear; sleepwear, bathrobes and dressing gowns; outer jackets, coats and shopcoats; dresses, skirts, suits, sets and co-ordinates; sportscoats, blazers and fine suits

2. Pants, shorts and overalls

3. Foundation garments

4. Underwear

5. Blouses, shirts, T-shirts and sweatshirts; tailored collar shirts; sweaters, pull-overs and cardigans

6. Hosiery

7. Textiles

8-14. Unrestricted categories comparable to categories 1-7.

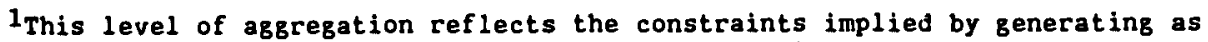
close as comparable cross-country data set as possible to cover trade under the different MFA quota categories used by the U.S., Canada, and the EEC. such a data set is currently unavailable from any other source. 


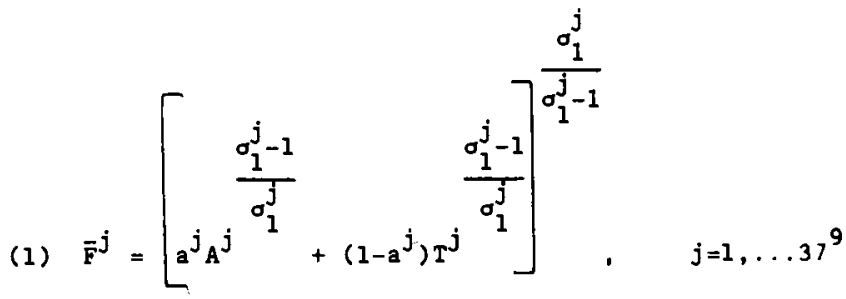

where

(2) $T^{j}=\delta^{j}\left[\sum_{i=1}^{l} b_{i}^{j} c_{i}^{j} \frac{\sigma_{2}^{j}-1}{\sigma_{2}^{j}}\right]^{\frac{\sigma_{2}^{j}}{\sigma_{2}^{j}-1}}, \quad j=1, \ldots 37$

and

(3) $c_{i}^{j}=\lambda_{i}^{j}\left[d_{i}^{j} x_{i}^{j} \sigma_{3 i}+\left(1-d_{i}^{j}\right) x_{\ell}^{j} \sigma_{3 i}\right] \quad, i=1, \ldots 7 ; \ell=i+7 ; j=1, \ldots 37$

This treatment implies that in production in each country $j$, there is first substitution between individual restricted textile products $\left(x_{i}^{j}\right)$ and comparable unrestricted products $\left(x_{\ell}^{j}\right)$, yielding composites of the products $\left(c_{i}^{j}\right)$, then between the composites $\left(c_{i}^{j}\right)$ yielding a composite textile product $\left(T^{j}\right)$; and finally between the composite $\left(T^{j}\right)$ and other goods $\left(A^{j}\right), \quad \sigma_{1}^{j}, \sigma_{2}^{j}$, and $\sigma_{3 i}^{j}$ are substitution elasticity parameters for country $j$ in this three level nesting structure, and the $a^{j}, s, b_{i}^{j} s$ and $d_{i}^{j}$ 's are share parameters, with $\sum b_{i}^{j}=1 . \delta^{j}$ and $\lambda_{i}^{j}$ are constants which define units for the composites appearing in the nesting hierarchy. The nesting hierarchy used in each country's production is shown in Figure 1. 


\section{Pigure 1}

\section{Nestins Structure Used to Represent Production In Bach Country}

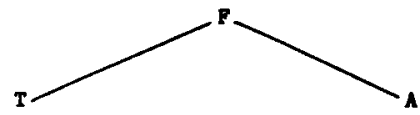

\section{Level 1}

(Substitution between textiles and apparel and other

manuf actures )

\section{Level 2}

(Substitution among 7 textile and apparel composites)

\section{Level 3}

(Substitution between quota restricted and comparable non-quota restricted textile and apparel comnodities)

$$
\text { (composite textile and }
$$
apparel commodity)

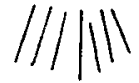

7 textile and apparel composites

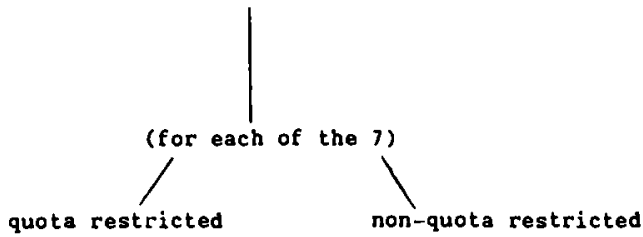


The composite other good is assumed to be freely traded. We use this as a numeraire, and set its price equal to unity in all countries. Hence, assuming profit maximizing behaviour, producers in each country choose quantities $x_{i}^{j}$ for each of the 14 product categories to maximize (4) $\sum_{i=1}^{14} P_{X i}^{j} x_{i}^{j}+A^{j}, \quad j=1, \ldots 37$ subject to (1), (2) and (3) where $\mathrm{P}_{\mathrm{Xi}}^{\mathrm{j}}$ are the prices prevailing in country $j$ for the fourteen textile and apparel commodities $x_{i}^{j}$.

since producers in all developing countries are assumed to supply to both the domestic as well as to the quota-restricted developed country markets, marginal production is valued at the domestic price. Because quotas in export markets are assumed to be binding, additional production by any firm is for the domestic not the foreign market. Quota rents accruing from sales to developed countries thus accrue in lump sum form to owners of firms, and do not affect the maximand (4).

This yields output supply functions

(5) $T^{j}=\frac{\bar{F}^{j}}{\frac{\sigma_{1}^{j}}{j^{j}}}, j=1, \ldots 37$ $\left[\frac{\sigma_{1}^{j}-1}{a^{j} D^{j}}\right]_{1}^{\frac{\sigma_{1}^{j}}{\sigma_{1}^{j}-1}}$

(6) $A^{j}=\left[\frac{\bar{F}^{j}-\left(1-a^{j}\right) T^{j}}{\frac{\sigma_{1}^{j}-1}{\sigma_{1}^{j}}}\right]^{\frac{\sigma_{1}^{j}-1}{\sigma_{1}^{j}}}, \quad j=1, \ldots 37$ 
(7) $c_{i}^{j}=$

$$
P_{C i}{ }_{2}^{j}\left[{ }_{{ }^{j}}^{7} b_{\ell=1}^{j}{ }^{\sigma_{l}^{j}} P_{C l}^{j} 1-\sigma_{2}^{j}\right]^{\frac{\sigma_{2}^{j}}{\sigma_{2}^{j}-1}}
$$<smiles>[3H][Y][AlH2]</smiles>

and,

(8)

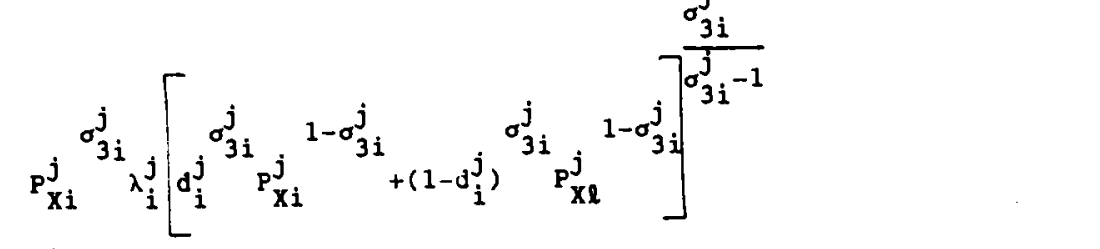

where

(9) $D=\left(\frac{P_{T}^{j} a^{j}}{1-a^{j}}\right)^{\sigma_{1}^{j}}, j=1, \ldots 37$

$P_{T}^{j}$ is the producer price in country $j$ for the composite textile product $T^{j}$, 
(10) $P_{T}^{j}=\frac{\left.\left[\sum_{i=1}^{7} b_{i}^{j}{ }^{\sigma_{2}^{j}} P_{C i}^{j}\right]^{1-\sigma_{2}^{j}}\right]^{\frac{1}{1-\sigma_{2}^{j}}}}{\delta^{j}}, j=1, \ldots 37$

and $P_{C i}^{j}$ are the producer prices in country $j$ for the 7 textile composites $c_{i}^{j}$,

(11) $P_{C i}^{j}=\frac{\left[d_{i}^{j}{ }^{\sigma_{3 i}^{j}} P_{C i}^{j} 1-\sigma_{3 i}^{j}+\left(1-d_{i}^{j}\right)^{\sigma_{3 i}^{j}}{ }_{C l}^{j} 1-\sigma_{3 i}^{j}\right]^{\frac{1}{1-\sigma_{3 i}^{j}}}}{\lambda_{i}^{j}}$,

$$
i=1, \ldots 7 ; \ell=i+7 ; j=1, \ldots .37
$$

\section{c) Consumption}

Consumer demands are generated from utility maximizing behaviour, with a single demand side agent assumed in each country. Each agents' utility function is of nested CES form, with a structure similar to that on the production side, i.e.,

(12) $u^{j}=\left[\begin{array}{cc}\frac{\hat{\sigma}_{1}^{j}-1}{a^{j} \hat{A}^{j}}+\left(1-a^{j}\right) i^{j} & \frac{\sigma_{1}^{j}-1}{\sigma_{1}^{j}}\end{array}\right]^{\frac{\sigma_{1}^{j}}{\sigma_{1}^{j}-1}}, j=1, \ldots 37$ 


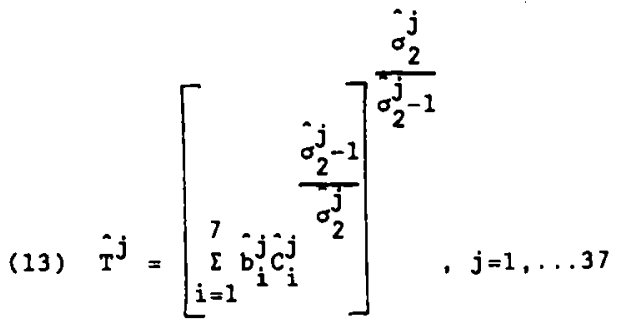

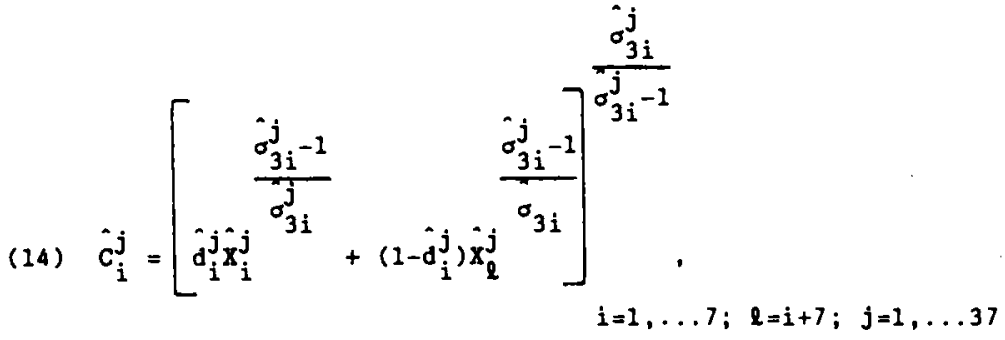

where $\sigma_{1}^{j}, \sigma_{2}^{j}$ and $\dot{\sigma}_{3 i}^{j}$ are elasticity parameters in country $j$, and the $\hat{a}^{j} \cdot s, \hat{b}_{i}^{j}, s$, and $\hat{d}_{i}^{j}$ 's are share parameters, with $\left[\hat{b}_{i}^{j}=1\right.$.

The budget constraint for the single agent in each country is (15) $\sum_{i=1}^{14} P_{X i}^{j} \dot{X}_{i}^{j}+\hat{A}^{j}=\sum_{i=1}^{14} P_{X i}^{j} X_{i}^{j}+A^{j}+R^{j}+Q^{j}, j=1, \ldots 37$

where $R^{j}$ are tariff revenues ${ }^{10}$ collected in country $j$, and $Q^{j}$ is the value of quota premia received on exports by country $j$, reflecting transfers of quota rents from developed countries. ${ }^{11}$ Tariff rates $t_{i}^{j}$ apply to imports of product category i by developed country $j$.

Maximizing (12) subject to (13), (14) and (15) yields the demand functions

(16) $\quad \hat{T}^{j}=\frac{I^{j}}{z^{j}+\hat{P}_{T}^{j}}, \quad j=1, \ldots 37$ 
(17) $\quad \hat{A}^{j}=I^{j}-\hat{P}_{T}^{j} \hat{T}^{j}, \quad j=1, \ldots 37$

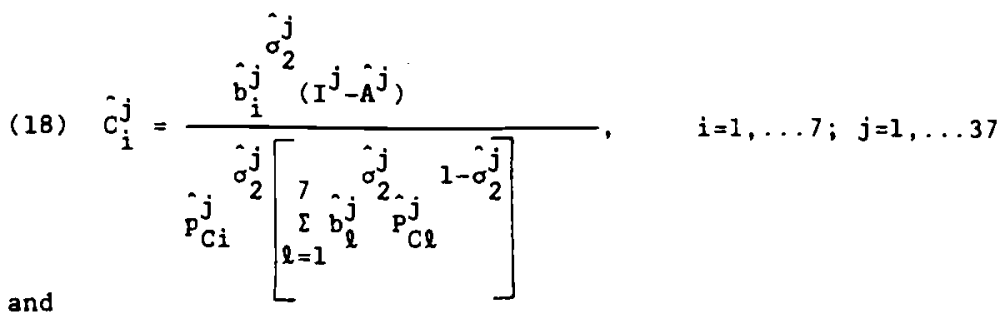

$$
\begin{aligned}
& \dot{d}_{i}^{j} \hat{\sigma}_{3 i}^{j}\left(I^{j}-\hat{A}^{j}-\sum_{m \neq i} \hat{P}^{j} \hat{c}^{c_{m}^{j}}\right) \\
& \text { (19) } \hat{x}_{i}=
\end{aligned}
$$

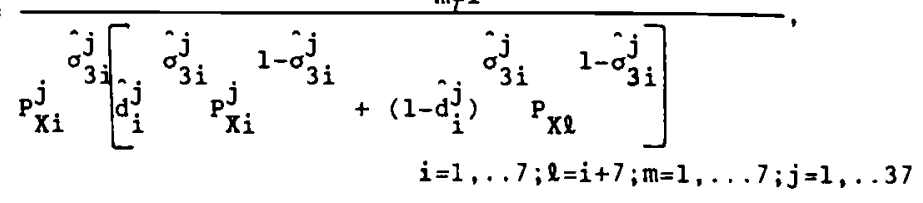

\section{where}

(20) $\quad I^{j}=\sum_{i=1}^{14} P_{X i}^{j} X_{i}^{j}+A^{j}+R^{j}+Q^{j}, \quad j=1, \ldots, 37$

(21) $z^{j}=\left(\frac{\hat{P}_{T}^{j} \hat{a}_{i}^{j}}{1-a_{i}^{j}}\right)^{\hat{\sigma}_{1}^{j}}, \quad j=1, \ldots 37$

$\hat{P}_{T}^{j}$ is the consumer price in country $j$ for the composite textile product $\hat{T}^{j}$.

(22) $\left.\hat{P}_{T}^{j}=\left[\sum_{i=1}^{i} i_{i}^{j} i_{i_{i}^{j}}^{j}\right]^{1-\sigma_{2}^{j}}\right]^{\frac{1}{1-\sigma_{2}^{j}}}, \quad j=1, \ldots 37$ 
and $\vec{P}_{\mathrm{C} i}^{j}$ are the consumer prices in country $j$ for the 7 textile composites $\hat{\mathrm{C}}_{i}^{j}$,

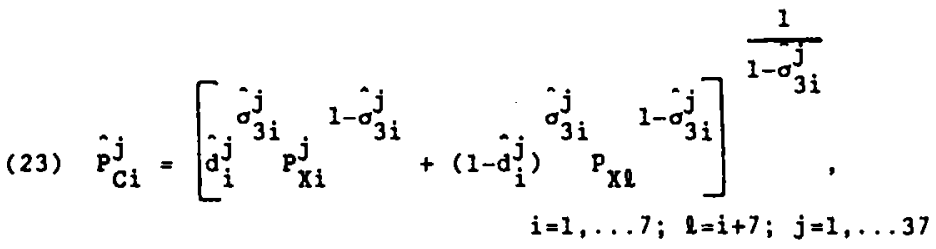

d) Trade

Each country's trade in the fourteen product categories, and in the composite other good is given by the difference between production and consumption. Thus, for each of the fourteen product categories, imports under product category $i$ by developed country $k$ from country $j, \mathrm{H}_{i}^{\mathbf{k j}}$, summed over supplying countries minus exports under product category $i$ by $k$ to developed country $n, E_{i}^{k n}$, sunumed over developed countries, are given by (24) $\sum_{j=1}^{37} H_{i}^{k j}-\sum_{n=1}^{3} E_{i}^{k n}=x_{i}^{k}-x_{i}^{k}, \quad i=1, \ldots 14 ; k=1, \ldots 3$

and exports by developing country $j$ to developed country $k, \varepsilon_{i}^{j k}(=$ $\mathbf{M}_{\mathbf{i}}^{\mathbf{k}}$ ) summed over developed countries are

(25) $\sum_{k=1}^{3} \varepsilon_{i}^{j k}=x_{i}^{j}-\hat{x}_{i}^{j}, \quad i=1, \ldots 14 ; j=4, \ldots 37$

Exports by developed country $k$ to developing country $j$ of the composite other good, $\varepsilon_{A}^{k j}$, summed over developing countries, equal the difference between production and consumption in the developed country, i.e. 
(26) $\sum_{j=4}^{37} E_{A}^{k j}=A^{k}-A^{k}, \quad k=1, \ldots 3$

and imports by developing country $j$ from developed country $k, \mathrm{M}_{A}^{j k}(=$ $E_{A}^{k j}$, summed over developed countries, equal desired imports by country j. i.e.

(27) $\sum_{k=1}^{3} M_{A}^{j k}=\hat{A}^{j}-A^{j}, \quad j=4, \ldots 37$

In equilibrium net trades in all products sum to zero across all countries. Imports of the fourteen textile and apparel products by the developed countries also have to satisfy the constraints implied by their bilateral quotas, i.e.

(28) $\mathbf{M}_{i}^{k j} \leq B_{i}^{-k j}, \quad i=1, \ldots 7 ; j=4, \ldots 37 ; k=1, \ldots 3$

where $\vec{B}_{i}{ }^{k j}$ are the quotas on imports of products in category $i$ by developed country $k$ from developing country $j$. These bilateral quotas have the effect of segmenting national markets such that different domestic prices will apply for each of the seven restricted product categories. In applying the model, we calibrate it to a data set in which developed country quotas are assumed to be binding, and then examine alternative counterfactual situations in which quotas are removed. 


\section{e) Equilibrium}

Equilibrium in the model is given by a set of country prices for the fourteen product categories relative to the price of the composite other good, and revenue and quota rents for each country $\left(P_{X i}^{\star_{j}}, R^{\star_{j}}, Q^{\star_{j}}\right)$ such that

(i) Markets clear for the fourteen product categories.

(29) $\sum_{j=1}^{37} \dot{x}_{i}^{j}=\sum_{j=1}^{37} x_{i}^{j}, \quad i=1, \ldots 14$

(ii) Markets clear for the composite other good.

(30) $\sum_{j=1}^{37} A^{j}=\sum_{j=1}^{37} A^{j}$

(iii) The government budget is balanced in each developed country (i.e. tariff revenues collected on imports equal revenues disbursed on the demand side of the economy).

(31) $R^{k^{j}}=\sum_{i=1}^{14} t_{i}^{j} P_{X i}^{j} \max \left(0, x_{i}^{j}-x_{i}^{j}\right), \quad j=1, \ldots 3$

where $t_{i}^{j}$ is the ad valorem tariff rate on imports of product category $i$ by country $j$,

(iv) Quotas are binding.

(32) $M_{i}^{k j} \leq \bar{B}_{i}^{-k j}, \quad i=1, \ldots 14 ; j=4, \ldots 37 ; k=1, \ldots 3$

and 
(v) Income from quota rents assumed when evaluating demands equals that transferred by the developed countries to each exporting country.

(33) $Q^{k j}=\sum_{k=1}^{3} \sum_{i=1}^{14}\left(P_{X i}^{k}-P_{X i}^{j}\right) \bar{B}_{i}^{k j}, \quad j=4, \ldots 37$

In solving the nodel for counterfactual equilibria associated with changes in or removal of bilateral quotas in the developed countries, a Newton method is used (see whalley (1985)). The size and direction of the Newton steps are determined by a Jacobian matrix containing the derivatives of commodity excess demand functions and government budget and quota rent imbalances with respect to prices, revenues, and quota premia. This method uses successive linear approximations to the excess demand functions which are solved each time for a zero of the functions, until a true equilibrium solution is obtained. 


\section{Data, Parameterization, and Elasticities}

To determine parameter values for the demand and prouluction functions in this model, we use calibration procedures similar to those widely used in other applied general equilibrium models (see Mansur and Whalley (1984)). We employ a multi-country microconsistent equilibrium data set for 1986 (described below), augmented by elasticities of transformation and substitution.

A number of data sources are used in assembling the microconsistent data set for 1986 on which model calibration is based. Data on the value of imports, by MFA product category and country of origin, are from the U.S. Department of Commerce $(1987 \mathrm{a}, 1987 \mathrm{~b}, 1987 \mathrm{c})$, Canadian Department of External Affairs (unpublished data, 1987), and the European Commission (1987). 12 The major problem with this data is that it is difficult to make comparisons across countries because of the different textile and apparel categories used in administering quotas in each country or region. since no such cross country data set currently exists, we have constructed as close as comparable 14-8ood cross-country data set as possible to produce trade data under the different aggregated MFA quota categories used in the model. This data is presented in Table 2 .

Data on the value of production in the U.S. for textiles and apparels in separate aggregate categories are taken from the U.S. Department of Conmerce (1987d), while data in Canada, the EEC and the developing countries are from the United Nations (1986). ${ }^{13}$ This data is disaggregated in order to provide estimates of production for the fourteen product categories in the model using the ratios of trade in the individual categories to total trade in the corresponding broad category (textiles or apparel) by country. For each model 


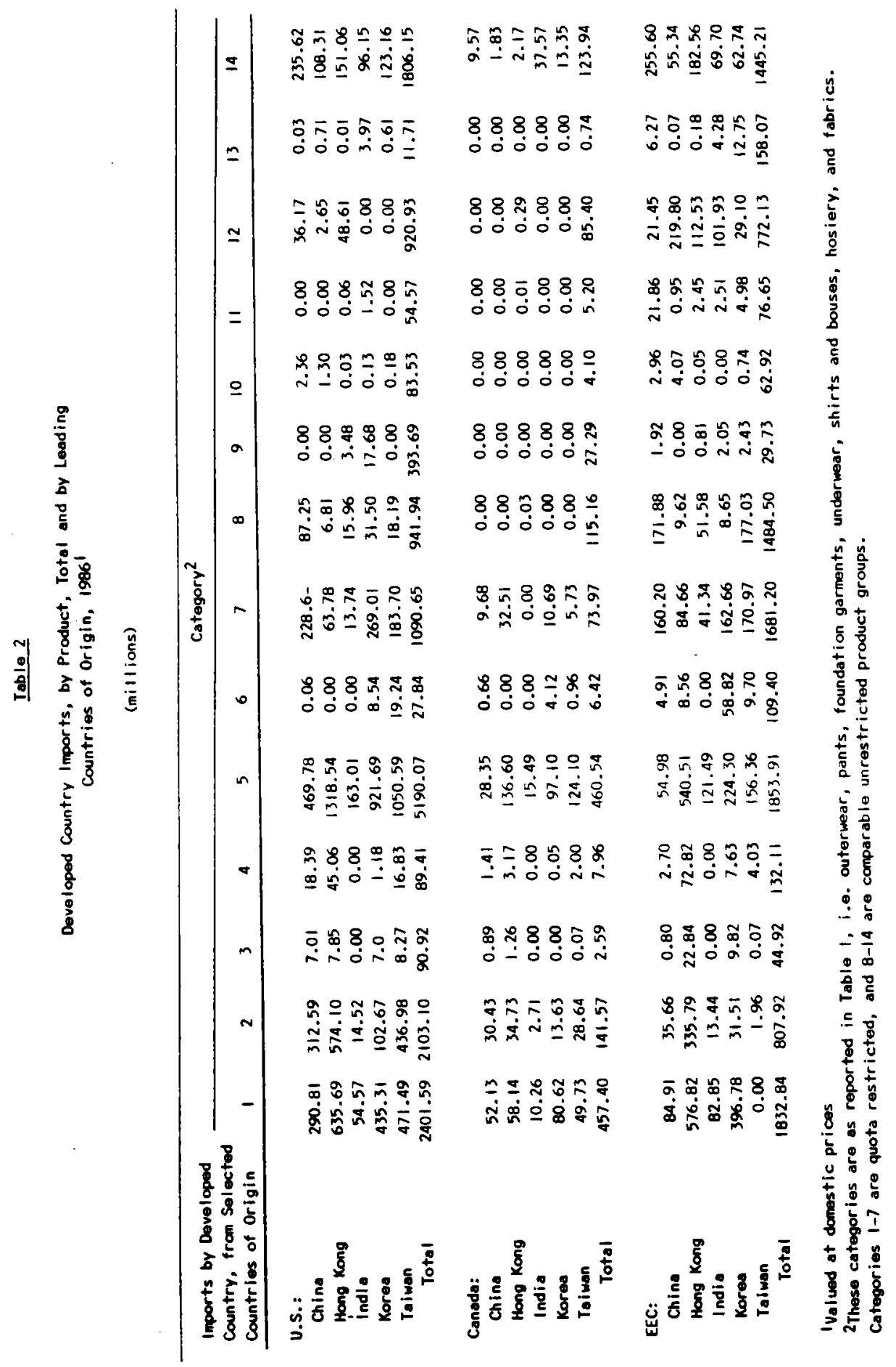


product in each country, the value of consumption is determined as the residual between the value of production and imports, on one hand, and the value of exports on the other hand.

As noted in the introduction, data on unit costs of production of individual textile and apparel products (supply prices) in the various developing countries are not currently available. While the unit costs of quota unrestricted products can be approximated by the U.S. price minus the tariff, the problem with data arises when we try to estimate supply prices of quota restricted products. These are central to any calculation of the impacts of developed country textile quotas, since they affect estimates of rent transfer per unit export.

Quotas are only freely traded in Hong Kong, with partial trading in Taiwan and no trading in South Korea, and so quota price data in a range of countries cannot be used. 14 Also quotas are not necessarily allocated to the most efficient producers within countries, and so even if actual costs of current producers were known, the minimum potential unit cost for each textile and apparel product in the various countries remains unknown. We, therefore, use an indirect method of estimating supply prices of quota restricted itens in developing countries closely related to that used by Hamilton (1988).

We use data on U.S. quota prices of $f$ ifteen product categories for Hong Kong for 1984, 15 based on calculations made by Hamilton (1986); 1982 quota prices are used in model sensitivity analyses reported on later. Both of these sets of price data are given in Table 3. U.S. quota prices of the other MFA products ${ }^{16}$ for Hong Kong are calculated on the basis of an average of the quota prices given in Table 3. In aggregating the MFA products in the U.S. into the seven restricted product categories used in the model, new quota prices are calculated by taking trade weighted averages of quota prices using the Hamilton data that fall within the categories used in the model. 


\title{
Table 3
}

\author{
U.S. Quota Prices ${ }^{1}$ for Textile Import Products \\ from Hong Kong from Hamilton (1986)
}

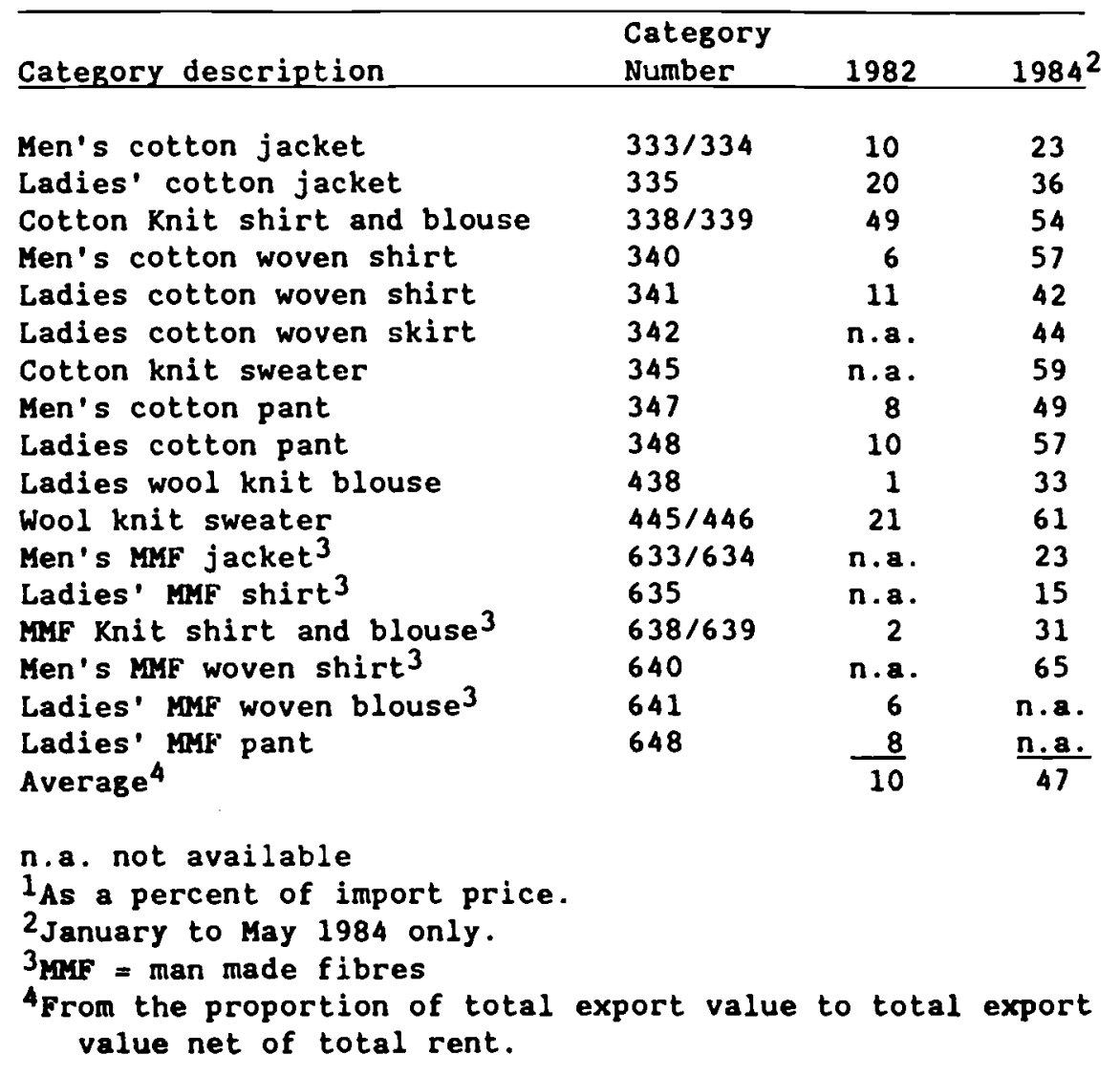


Our method of calculating production costs of quota restricted items in other supplying countries is to assume that for each product category, the unit cost can be approximated by the unit cost in Hong Kong multiplied by the ratio of the supplying country's relative wage rate in textile and apparel compared to Hong Kong. We apply a further correction for the relative efficiency of labor and product quality across countries by also multiplying by each country's relative value of gross output per worker in textiles and apparel compared to Hong Kong. This makes a large difference to estimated supply prices. ${ }^{17}$ value of gross output per worker is given by dividing wages per employee by wages in value added, and then dividing by value added in gross output. Data on wages per employee, value added in gross output and wages in valued added, for textiles and apparel are from UNIDO (1985). The resulting average ${ }^{18}$ supply prices of quota restricted products by country, both adjusted and unadjusted for differences in labour productivity and product quality, and for both 1982 and 1984, are presented in Table 4. As can be seen the correction for labour productivity and product quality makes a very large difference to these estimates; as large as a factor of ten in some cases.

The value of production of other goods in all countries is given by subtracting the value of production of textile and apparel products from GDP in each country. Data on GDP by country are from the World Bank (1986) and from Europa (1987). External sector balance conditions are then used to calculate the value of trade in other goods in each country.

The model also requires elasticity values for transformation surfaces and preferences in each country. For the bottom level of nesting, assumed values of -0.50 and 5.0 are used for all pairwise nests between comparable restricted and unrestricted commodities and in all countries. Given there are 


\section{Table 4}

Average Supply Prices of Quota Restricted

Textiles and Apparel by Country 1982 and 1984

Adjusted
for differences in
labour productivity
and product quality

Exporting Country
1984

0.35

0.31

0.67

0.55

0.47

0.68

0.62

0.68

0.59

0.59

0.55

0.68

0.53

0.55

0.52

0.49

0.59

0.46

0.52

0.59

0.55

0.55

0.68

0.59

0.62

0.67

0.59

0.62

0.55

0.59

0.59

0.31

0.63

0.57
Unadjusted

for differences in labour productivity and product quality

1982

1984
0.04

0.34

0.43

0.11

0.35

0.42

0.60

0.36

0.18

0.34

0.14

0.11

0.23

0.09

0.09

0.43

0.69

0.22

0.18

0.72

0.06

0.12

0.54

0.34

0.14

0.43

0.77

0.62

0.13

0.67

0.22

0.40

0.74

0.52
0.04

0.30

0.37

0.10

0.31

0.37

0.53

0.31

0.15

0.30

0.13

0.68

0.20

0.08

0.08

0.38

0.60

0.19

0.16

0.63

0.05

0.10

0.47

0.30

0.12

0.37

0.68

0.54

0.11

0.59

0.19

0.35

0.65

0.45

Uruguay
Yugoslavia

0.72

0.66

Source: Based on data from Hamilton (1986) and methods described in the text. 
no literature estimates to guide the choice of these values we justify our specification as follows. An assumption of smooth substitutability in production between comparable restricted and unrestricted commodities would not be appropriate, since there would be no effect of the quotas. Therefore, a low elasticity value is used for all countries, implying a limited ability to substitute products on the supply side. In contrast, a high degree of substitutability is assumed on the demand side of the model. This has some claim to plausibility since from the consumers point of view the relative difference in product characteristics is small.

Elasticity values at the top two levels are calculated as follows. For the developed countries, we base our selection of these values on estimates of U.S. total demand elasticities and assumed supply elasticities of 1.5. For the developing countries, we assume a Cobb-Douglas specification for both transformation and preference functions, which is equivalent to setting all these elasticities to unity. ${ }^{19}$ Because of the potentially crucial nature of these elasticity values for model behaviour, we use a central set of elasticity values around which sensitivity analyses are performed.

The U.S. total demand elasticity of -0.60 is based on estimates of this elasticity for textiles and apparel, reported in cline (1987). Since no comparable information on supply elasticities is available we use a value of 1.5, which is intermediate to a range of assumed values used by other researcher's (see, for instance, Jenkins and Greenaway op. cit.). We calculate implied elasticities of transformation and substitution for the top two levels of nesting in the developed countries ${ }^{20}$ consistent with these estimates. These values are, however, not necessarily consistent with literature 
estimates of import demand elasticities for textiles and apparel, 21 reflecting the well known incompatibilties between literature estimates of demand and supply elasticities on the one hand, and import demand elasticities on the other.

The calibration procedures used to generate the parameter values for the model involve first decomposing the data represented in value terms into separate price and quantity data. This is done through a units convention which defines physical units for all conmodities as those amounts which in equilibrium, sell in the U.S. for $\$ 1$. Hence domestic prices in developing countries for quota restricted items are less than one, and domestic prices in Canada and the EEC are less than, greater than, or equal to one, depending upon the direction of trade. Once elasticity values have been selected, share parameters for the CES and CET functions in the model are given from the price and quantity data and the assumption of agent optimization in each country.

For instance, first order conditions from profit maximization allow the share parameters $a^{j}, b_{i}^{j}$, and $d_{i}^{j}$ to be calculated as

$$
a^{j}=\frac{1}{1+P_{T}^{j}\left(\frac{A^{j}}{T^{j}}\right)^{\frac{\sigma_{1}^{j}}{1}}}, \quad j=1, \ldots 37
$$

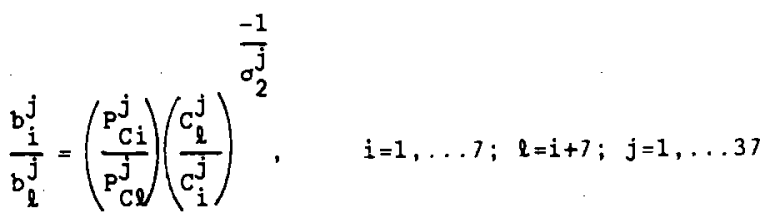


(36) $d_{i}^{j}=\frac{1}{1+\left(\frac{P_{x l}^{j}}{P_{x i}^{j}}\right)\left(\frac{x_{i}^{j}}{x_{l}^{j}}\right)^{\frac{-1}{\sigma_{3 i}}}}, \quad i=1, \ldots 7 ; l=i+7 ; j=1, \ldots 37$

A similar procedure can be used to calculate the demand side share parameters $a^{j}, b_{i}^{j}$ and $i_{i}^{j}$. 


\section{Results}

The general equilibrium model described above has been used to analyze a variety of possible changes in quota and tariff restrictions used by developed countries towards imports of textiles and apparel. In these analyses major focus is on welfare effects, reported as Hicksian equivalent variations (EVs) ${ }^{22}$ by country in billions of 1986 dollars, but trade volume and production effects are also reported. We have also made calculations using the simple one developed country version of the same model in which the size of developing countries is changed. Results using this version of the model provide a basis for comparison on the issue of rent transfer effects and the treatment of developed countries as small open economies, as assumed in partial equilibrium analyses. We first report calculations made using the basic variant of our model where the three major developed countries and the 34 developing countries are considered, and evaluate the effects of abolishing developed country bilateral quotas and/or tariffs covering the fourteen textile product categories considered by the model. Table 5 presents the welfare, production, and trade effects of removing both developed country bilateral quotas and tariffs on the fourteen textile products covered by the model. Results clearly show that all developing countries gain from the removal of restrictions on trade in textiles and apparel, with some gaining proportionately more than others. The effects by country reflect the price changes in each country, as well as the rent transfer effects of the bilateral quotas. In aggregate, developing countries gain $\$ 11.29$ billion, suggesting that gains to developing countries from improved access more than of losses from forgone rent transfers as the MFA is abolished. This is even the case for relatively larger holders of quotas such as Korea, Hong Kong, and other higher income NICS, whom it has always been argued, have a protected 


\section{Table 5}

Ceneral Equilibrium Effects of Removing Bilateral, MFA

Quotos and Tariffs in all Developed Countries'

Hicksian EV's

(\$ billions 1986)
Change in value of production of textiles at benchmark prices

(\$)
$-6.34$

$-6.06$

$-4.72$
Change in value of imports or exports of textiles at benchmark prices
United States

Canada

EEC

Exporting Countries
0.34

1.03

0.00

2.34

0.36

0.14

0.01

0.01

0.07

0.00

0.01

0.24

0.14

0.16

0.45

2.09

0.02

0.24

0.04

0.18

0.02

0.02

0.00

0.06

0.25

0.20

0.17

0.59

0.09

1.40

0.06

0.81

0.01

0.12

11.29

17.25
(8)

243.94

213.96

263.64
57.80

67.39

8.58

11.68

30.88

13.64

10.79

7.09

13.78

12.62

18.24

13.30

20.07

6.13

46.86

31.94

0.94

43.40

27.51

9.43

16.45

16.47

15.98

13.21

26. 31

12.29

24.44

31.42

41.12

25.06

26.34

22.30

12.62

11.07
329.67

400.27

58.42

425.44

899.94

484.52

35.89

21.11

790.93

214.28

48.57

45.61

181.97

129.35

409.16

241.04

11.45

189.62

118.39

380.55

200.85

29.63

71.98

356.11

179.28

432.15

150.29

88.43

103.22

207.84

63.43

108.63

85.57

63.94

All Developing

Countries

AlI Countries

\footnotetext{
Transformstion and substitution elasticities set equal to -0.5 and 5.0 in the bottan level of nesting for all countries in the model. In the top two levels, elasticities of transformation and substitution in all developed countries reflect literature estimates of U.S. total demand elesticities and assumed supply elasticities of 1.5. The elasticities are -0.50 and 1.60 in all developed countries. Cobb-Douglas specifications are used at the top two levels in all developing countries.
} 
market niche against lower cost competition under the MFA. In the presence of quotas they, along with other developing countries, are non-marginal suppliers to developed country markets. Removing quotas improves all supplying developing country's market share in developed country markets rather than reallocating share among them.

The global welfare gain is $\$ 17.25$ billion with gains to the U.S. of $\$ 2.59$ billion. This estimate is significantly lower than that of Cline (1987) who places the net welfare cost of textile and apparel protection in the U.S. at around $\$ 8$ billion using 1986 data. However, Cline uses a partial equilibrium approach which tends to overstate the welfare costs of protection to the U.S., because it implies full rent transfer. Importantly, this difference in results occurs even though our model captures the added costs of bilateralism in these trade restrictions, while cline does not.

In Table 6 we report results where bilateral quotas alone are removed, leaving tariffs in place. In this case all developing countries are worse off compared to the case in Table 5 , because their market access is reduced by developed country tariffs. Even larger gains result for the developed countries. This reflects their more advantageous terms of trade as a result of not also eliminating their tariffs, indicating that in the non-small open economy case, optimal tariffs for developed countries are non-zero, and that 1986 tariff levels are below optimal tariffs. This again emphasizes the difference in the analysis from the small open economy case.

The sensitivity of these results has been tested through a series of experiments reported on in Tables 7,8 and 9 . Table 7 reports the impacts on results of various changes in elasticity values for transformation surfaces and preferences in each country. Table 8 provides an indication of the magnitudes involved as assumptions on supply prices by country are changed.

Table 9 reports the effects on results if the composite other good is defined to be other manufactures instead of residual GDP 23 
Walfore and Trada Effects of Removing Bilateral Quotas But Not Tariffs'

Hicksian EV's

(\$ billions 1986)

Change in value of production of textiles at benchmark prices

(8)

United States
Caneda
EEC

5.16

0.36

5.41

-3.38
-2.62

$-4.95$

Change in value of imports or exports of textiles ot benchmark prices (B)

Exporting Countries

\begin{tabular}{|c|c|c|c|}
\hline $\begin{array}{l}\text { Bangladesh } \\
\text { Brazil } \\
\text { Bulgaria } \\
\text { China } \\
\text { Columbia } \\
\text { Czechoslovakia } \\
\text { Costa Rica } \\
\text { Dominican Republic } \\
\text { Egypt } \\
\text { Guatemala } \\
\text { Hoiti } \\
\text { Hong Kong } \\
\text { Hungary } \\
\text { India } \\
\text { Indonesia } \\
\text { Korea } \\
\text { Mocou } \\
\text { Malaysia } \\
\text { Mauritius } \\
\text { Mexico } \\
\text { Nopal } \\
\text { Pakistan } \\
\text { Panamo } \\
\text { Peru } \\
\text { Philippines } \\
\text { Poland } \\
\text { Romania } \\
\text { Singapore } \\
\text { Sri Lanka } \\
\text { Toiwan } \\
\text { Thailand } \\
\text { Turkey } \\
\text { Uruguay } \\
\text { Yugoslavia }\end{array}$ & $\begin{array}{r}0.25 \\
0.81 \\
0.00 \\
1.11 \\
0.27 \\
0.04 \\
0.00 \\
0.00 \\
0.03 \\
0.00 \\
0.00 \\
-0.40 \\
0.07 \\
0.00 \\
0.20 \\
1.10 \\
-0.03 \\
0.15 \\
0.02 \\
0.06 \\
0.01 \\
-0.01 \\
0.00 \\
0.03 \\
0.10 \\
0.08 \\
0.04 \\
-0.02 \\
0.01 \\
0.40 \\
-0.02 \\
0.48 \\
0.00 \\
0.00\end{array}$ & $\begin{array}{r}13.07 \\
56.66 \\
-0.06 \\
6.89 \\
23.73 \\
7.31 \\
0.41 \\
-2.06 \\
8.48 \\
6.00 \\
8.95 \\
6.44 \\
14.12 \\
2.31 \\
31.30 \\
24.48 \\
0.70 \\
34.36 \\
19.80 \\
4.28 \\
10.28 \\
9.49 \\
3.99 \\
7.52 \\
16.98 \\
5.92 \\
13.63 \\
17.89 \\
27.72 \\
16.20 \\
15.42 \\
15.81 \\
6.75 \\
5.88\end{array}$ & $\begin{array}{r}211.46 \\
319.83 \\
-9.39 \\
241.32 \\
651.71 \\
253.25 \\
-0.50 \\
-6.94 \\
490.95 \\
98.49 \\
20.94 \\
24.48 \\
122.03 \\
41.45 \\
275.42 \\
184.77 \\
12.85 \\
146.45 \\
81.83 \\
163.89 \\
120.29 \\
16.84 \\
22.02 \\
199.24 \\
113.55 \\
198.72 \\
80.17 \\
51.57 \\
69.67 \\
138.61 \\
36.91 \\
72.80 \\
45.75 \\
34.13\end{array}$ \\
\hline $\begin{array}{l}\text { All Dovelaping } \\
\text { Countries } \\
\text { All Countries }\end{array}$ & 4.83 & & \\
\hline
\end{tabular}

132.78

84.45

253.94
211.46

$-9.39$

41.32

$-0.50$

6.94

98.49

0.94

41.45

12.85

6.45

163.89

0.29

2.02

9.24

80.17

38.61

36.91

4.13

Transformation and substitution elasticities set equal to -0.5 and 5.0 in the bottam level of nesting for all countries in the model. In the top two levels, elasticities of transformation and substitution in all developed countrles reflect literature estimates of U.S. total demand elasticities and assumed supply elasticities of 1.5. The asticitles are -0.50 and 1.60 in all develaped countries. Cobb-Douglas specifications are used at the top two levels in all developing countries. 


\section{Table 7}

Effects of Changes in Elasticity Velves on Results

(Hicksian Equivalent Variations in billions of 1996 dollars)

$\begin{array}{lrrr} & \text { Cose 1 } & \text { Case 2 } & \text { Case 3 } \\ \text { Unitod States } & 3.02 & 0.51 & 3.49 \\ \text { Canada } & 0.27 & 0.08 & 0.38 \\ \text { EEC } & 3.34 & 2.18 & 4.88\end{array}$

Exporting Countries

\begin{tabular}{|c|c|c|c|}
\hline $\begin{array}{l}\text { Bangladesh } \\
\text { Brazil } \\
\text { Bulgaria } \\
\text { China } \\
\text { Columbia } \\
\text { Czechos lovakia } \\
\text { Costa Rica } \\
\text { Damin ican Republic } \\
\text { Egypt } \\
\text { Guatemala } \\
\text { Haiti } \\
\text { Hong Kong } \\
\text { Hungary } \\
\text { India } \\
\text { Indonesia } \\
\text { Korea } \\
\text { Macau } \\
\text { Malaysia } \\
\text { Mauritius } \\
\text { Mexico } \\
\text { Nepal } \\
\text { Pakistan } \\
\text { Panama } \\
\text { Peru } \\
\text { Phi lippines } \\
\text { Poland } \\
\text { Ramania } \\
\text { Singapore } \\
\text { Sri Lanka } \\
\text { Taiwan } \\
\text { Thailand } \\
\text { Turkey } \\
\text { Uruguay } \\
\text { Yugos lavia }\end{array}$ & $\begin{array}{l}0.32 \\
0.99 \\
0.00 \\
2.09 \\
0.34 \\
0.12 \\
0.01 \\
0.01 \\
0.06 \\
0.00 \\
0.01 \\
0.11 \\
0.13 \\
0.13 \\
0.39 \\
1.90 \\
0.01 \\
0.22 \\
0.03 \\
0.14 \\
0.02 \\
0.01 \\
0.00 \\
0.06 \\
0.22 \\
0.18 \\
0.14 \\
0.04 \\
0.07 \\
1.19 \\
0.04 \\
0.74 \\
0.00 \\
0.09\end{array}$ & $\begin{array}{l}0.32 \\
0.86 \\
0.01 \\
2.14 \\
0.33 \\
0.13 \\
0.02 \\
0.03 \\
0.06 \\
0.01 \\
0.02 \\
0.46 \\
0.14 \\
0.21 \\
0.37 \\
1.80 \\
0.04 \\
0.22 \\
0.04 \\
0.19 \\
0.02 \\
0.04 \\
0.00 \\
0.06 \\
0.25 \\
0.21 \\
0.17 \\
0.07 \\
0.08 \\
1.23 \\
0.07 \\
0.68 \\
0.01 \\
0.17\end{array}$ & $\begin{array}{l}0.62 \\
1.67 \\
0.00 \\
2.93 \\
0.52 \\
0.16 \\
0.02 \\
0.01 \\
0.08 \\
0.01 \\
0.02 \\
0.22 \\
0.21 \\
0.21 \\
0.52 \\
2.56 \\
0.03 \\
0.34 \\
0.05 \\
0.21 \\
0.03 \\
0.03 \\
0.00 \\
0.08 \\
0.32 \\
0.26 \\
0.21 \\
0.05 \\
0.10 \\
1.50 \\
0.07 \\
1.22 \\
0.01 \\
0.17\end{array}$ \\
\hline $\begin{array}{l}\text { A I Developing } \\
\text { Countries }\end{array}$ & 9.97 & 10.60 & 14.62 \\
\hline A 1 I Countries & 16.61 & 13.39 & 23.39 \\
\hline
\end{tabular}

Case 1: As in Table 5, but with Cobb-Douglas specifications used at the top two levels of nesting of transformation and preference functions in all developed countries.

Case 2: As in Table 5 but with both transformation and substitution elasticities set equal to 0.50 in the top two levels of nesting in all developing countries in the model.

Cose 3: As in Table 5, but with transformation and substitution elasticities set equal to -2.5 and 7.0 in the bottom level of nesting in all countries in the model. 


\section{Table B}

Effects of Chenges In Assumptlons on Supply Prlces and Other Sensitivy Analyses on Results (Hicksian Equivalent Variations in billions of 1996 dollars?

$\begin{array}{lcccr} & \text { Case } 1 & \text { Case 2 } & \text { Case 3 } & \text { Cose 4 } \\ \text { United States } & 2.59 & 0.88 & 23.67 & 2.51 \\ \text { Canado } & 0.24 & 0.06 & 2.00 & 0.24 \\ \text { EEC } & 3.11 & 1.44 & 18.23 & 3.09\end{array}$

Exporting Countries

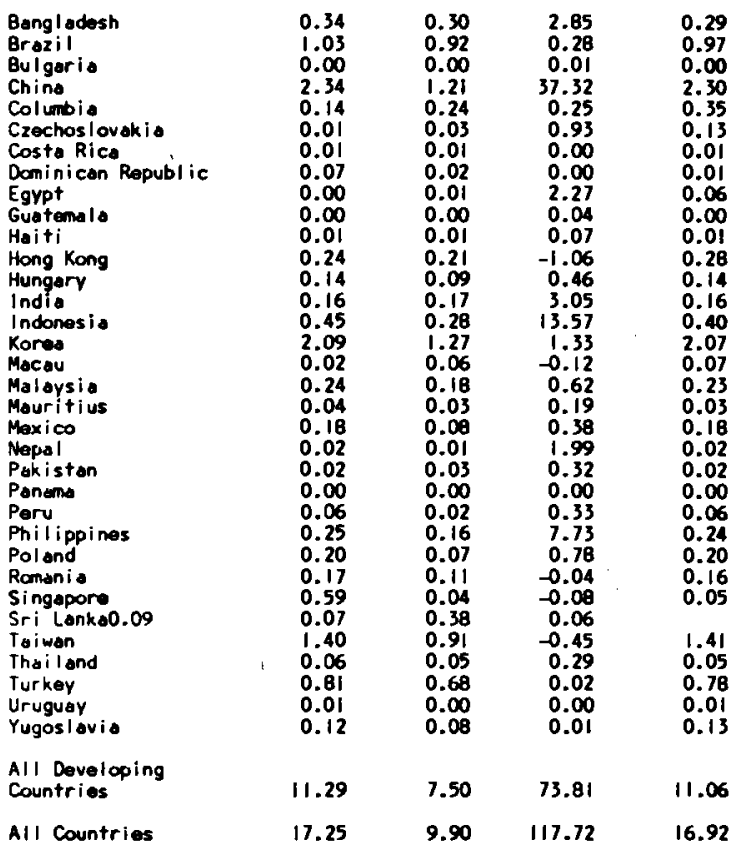

Cose 1: As in Table 5.

Case 2: As in Table 5, except that supply prices in Hong Kong are besed on 1982 quoto prices.

Case 3: As in Table 5, except that for each developing country the ratio of their relative wage rate (compared to the Hong Kong basel is used as an indicotor of relotlve product price at international values. Mo eccount is taken for differences in labour productivity or product quality.

Case 4: As In Toble 5, except thet the composite other good is defined to be other manufectures insteed of residual GOP. 
Results in Table 7 suggest that for some of the countries results are highly sensitive to changes in elasticities, while others are less so. The degree of sensitivity seems to be collinear with the size of the country price effects, and corresponding quantity effects, which are produced when tariffs and quotas are eliminated. If supply prices for quota restricted products in Hong Kong are calculated using 1982 rather than 1984 quota prices (Case 2 of Table 8 ), supply prices in all developing countries for these products rise. Both the welfare estimates and the size of quota rents transferred to foreigners are reduced when this happens.

Case 3 of Table 8 shows that if relative wage rates (compared to Hong Kong) are used as an indicator of relative product supply prices, this has a significant impact on our welfare measures. Prices of quota restricted products decrease considerably in all developing countries, except Brazil, Macau, Mexico, Romania, Turkey and Uruguay where prices increase. The effect of decreasing supply prices is to expand the differentials between foreign production costs and the price paid by importers. As a result, developed countries gain even more from elimination of textile and apparel protection. Some developing countries are worse off, while others are better of $f$. In aggregate they gain more, despite greater forgone rent transfers. Finally, results in column 4 of Table 8 show that using an alternative definition of the composite other good to cover only other manufactures rather than residual GDP does not have large effects on results.

To illustrate how important assumptions on country size are when evaluating rent transfer effects, we report some calculations made using the simple version of our model, where only the U.S. and the 34 developing countries are considered. We consider the effects of abolishing both U.S. bilateral quotas and tariffs. 
Table 9 shows the overestimate of the effects obtained when the size of developing countries is increased in the base period data to which the model is calibrated, since greater rent transfers to exporting countries occur. Estimates of welfare effects of both developing and developed countries differ by almost a factor of 1.5 , even though quota premia and elasticity values underlying the calculation are the same. Both the welfare estimates and the size of quota rents transfered to foreigners are reduced when the size of developing countries is decreased. These results suggest that treating developed countries as price takers as in partial equilibrium calculations tends to overestimate the effects of quota and tariff restrictions on U.S. welfare.

Comparing Case 1 of this Table with the results in Table 5, where quotas changes also occur in the EEC and Canada provides some sense of trade diversion effects of quotas between developed countries. ${ }^{24}$ The estimate for the cost of U.S. restrictions only considering the developing countries is more than two times that when all developed countries remove their quotas, since the trade diversion effects which occur between the U.S. and the other developed countries do not enter the calculation in rable 9.

\section{v. Concluding Remarks}

This paper analyzes the impacts of bilateral quota restrictions used by three major developed countries against textile and clothing imports under the Multifibre Arrangement from developing countries. A numerical general equilibrium model of global trade in fourteen key textile and apparel categories involving 3 developed and 34 developing countries is used. 


\section{Table 9}

\section{A Comparison of the Effects of Changes In Country SIze}

on Estimates of Removing U.S. Bilateral Quotas and Tariffs (Hicksian Equivalent Varlations in blilions of 1986 dollars)

$\begin{array}{rrr}\text { Case } 1 & \text { Case 2 } & \text { Case 3 } \\ 5.60 & 10.29 & 3.68\end{array}$

United States
Exporting Countries

\begin{tabular}{|c|c|c|c|}
\hline $\begin{array}{l}\text { Bangladesh } \\
\text { Brazil } \\
\text { Bulgaria } \\
\text { China } \\
\text { Col umbia } \\
\text { Czechoslovakia } \\
\text { Costa Rica } \\
\text { Dominican Republic } \\
\text { Egypt } \\
\text { Guatemala } \\
\text { Haiti } \\
\text { Hong Kong } \\
\text { Hungary } \\
\text { India } \\
\text { Indonesia } \\
\text { Korea } \\
\text { Macau } \\
\text { Malaysia } \\
\text { Mauritius } \\
\text { Maxico } \\
\text { Nepol } \\
\text { Pakistan } \\
\text { Panama } \\
\text { Peru } \\
\text { Philippines } \\
\text { Poland } \\
\text { Romania } \\
\text { Singapore } \\
\text { Sri Lanka } \\
\text { Taiwan } \\
\text { Thai land } \\
\text { Turkey } \\
\text { Uruguay } \\
\text { Yugoslavia }\end{array}$ & $\begin{array}{l}0.24 \\
0.47 \\
0.07 \\
1.16 \\
0.26 \\
0.03 \\
0.01 \\
0.02 \\
0.02 \\
0.00 \\
0.01 \\
0.11 \\
0.07 \\
0.12 \\
0.34 \\
1.61 \\
0.01 \\
0.14 \\
0.01 \\
0.06 \\
0.01 \\
0.00 \\
0.00 \\
0.03 \\
0.18 \\
0.14 \\
0.02 \\
0.03 \\
0.03 \\
0.67 \\
0.01 \\
0.61 \\
0.04 \\
0.19\end{array}$ & $\begin{array}{l}0.34 \\
0.82 \\
0.04 \\
1.05 \\
0.35 \\
0.02 \\
0.01 \\
0.02 \\
0.01 \\
0.00 \\
0.01 \\
-0.13 \\
0.08 \\
0.13 \\
0.35 \\
1.85 \\
0.00 \\
0.21 \\
0.02 \\
0.06 \\
0.01 \\
0.00 \\
0.00 \\
0.03 \\
0.20 \\
0.10 \\
0.02 \\
0.00 \\
0.01 \\
0.59 \\
0.00 \\
0.93 \\
0.02 \\
0.19\end{array}$ & $\begin{array}{l}0.21 \\
0.38 \\
0.08 \\
1.20 \\
0.23 \\
0.03 \\
0.01 \\
0.02 \\
0.02 \\
0.00 \\
0.00 \\
0.11 \\
0.06 \\
0.12 \\
0.33 \\
1.51 \\
0.02 \\
0.12 \\
0.02 \\
0.07 \\
0.01 \\
0.00 \\
0.00 \\
0.03 \\
0.17 \\
0.16 \\
0.02 \\
0.04 \\
0.03 \\
0.70 \\
0.01 \\
0.52 \\
0.02 \\
0.18\end{array}$ \\
\hline $\begin{array}{l}\text { All Developing } \\
\text { Countries }\end{array}$ & 6.89 & 7.51 & 6.61 \\
\hline Al| Couritries & 12.49 & 17.81 & 10.29 \\
\hline
\end{tabular}

Case 1: Developing country size reflects benchmark data set.

Case 2: Developing country size is two times that of the benchmark.

Case 3: Developing country size is three quarters that of the benchmark.

I Iransformation and substitution elasticities set equal to -0.5 and 5.0 in the botton level of nesting for all countries in the model. In the top two levels, elasticity values of -0.5 and 1.60 for transformation surfaces and preferences in the U.S. reflect literature estimates of U.S. total demand elasticities and an assumed supply elasticity of 1.5. Cobb-Douglas specifications are used at the top two levels in all developing countries. 
In the model, countries are represented by their actual size in terms of GDP, weakening rent transfer effects compared to partial equilibrium analysis.

We evaluate both the national and global welfare costs of the bilateral quotas captured by the model. Using data for 1986, results suggest global gains from elimination of quotas and tariffs of over $\$ 17$ billion. The largest part of these accrue to the developing countries who, in aggregate, gain around $\$ 11$ billion. This suggests that despite foregone rent transfers, developing countries would receive gains from eliminating textile and apparel protection through improved access to developed country markets.

Results also show all developing countries gaining in the central variant of the model from an elimination of the MFA, contrary to popular belief which suggests that higher income large quota recipient countries (such as Hong Kong, South Korea and Taiwan) would lose. In the model, since all of the developing country suppliers are quota constrained and relatively small compared to large developed countries, they increase their market share at the expense of developed country producers rather than lose share to other developing countries.

Estimates of the gains to the U.S. from the model for the removal of quotas are significantly lower than those of other partial equilibrium studies, such as Cline (1987), who places the net welfare cost of textile and apparel protection in the U.S. at around $\$ 8$ billion, rather than the $\$ 3$ billion reported here. This divergence in results occurs even though our model captures the added costs of bilateralism. The difference stems from the partial equilibrium assumptions of price taking behaviour for large developed countries, which will tend to cause the costs of textile and apparel protection to be overstated. As might be expected, results show sensitivity with respect to elasticity parameters and assumptions as to how supply prices vary across countries, but the main themes of results remain. 


\section{Notes}

1. In the paper we will use the the combination of terms "textiles", "textiles and apparel" and "textile products" interchangeably to refer to clothing, fabrics, and yarns.

2. There are, however, other effects of these restrictions not adequately captured by our approach. The most important is substitution into higher quality due to quotas (see Falvey (1979)). Quantifying quality effects due to textile quotas is extremely difficult, and to our knowledge has yet to be attempted.

3. The predecessor for the MFA was the 1961 Short-Term Arrangement Regarding International Trade in Cotton Textiles. This was followed in 1962 by a comparable Long-Term Arrangement, which expired in 1973.

4. Most developed countries continue to impose tariffs on textile imports. Over the years GATT negotiations have slightly reduced these tariffs, but not to the same degree as for other manufactured products.

5. These are: Bangladesh, Brazil, Bulgaria, China, Columbia, Czechoslovakia, Costa Rica, Dominican Republic, Egypt, Guatemala, Haiti, Hong Kong, Hungary, India, Indonesia, Republic of Korea, Macau, Malaysia, Mexico, Nepal, Pakistan, Panama, Peru, Philippines, Poland, Romania, Singapore, Sri Lanka, Taiwan, Thailand, Turkey, Uruguay, and Yugoslavia.

6. We define the composite other good to be residual GDP in the basic variant our model; 'other manufactures' are used in our sensitivity analysis reported on later. 
7. We were unable to include all the MFA quota categories in each country since they include products which belong to more than one of the fourteen specific product categories we identify in our model. The categories not included are: handkerchiefs (categories 330 and 630). gloves $(331,431$ and 631$)$ and other apparel $(359,459,659)$ in the U.S.; work gloves (31) and swinwear (44) in Canada; and handkerchiefs (19), knitted gloves (10), swinwear (72), shawls and scarves (84), woven ties (85), and other clothing accesories (88) in the EEC.

8. The index $i$ runs from $1, \ldots 7$ for the restricted products and for the unrestricted products from $8, \ldots 14$.

9. The index $j$ runs from $1, \ldots 3$ for developed countries and for developing countries from $4, \ldots 37$.

10. In numerically solving the model, we also introduce non-distorting production taxes in the developed countries on all products. Without these taxes, government revenue arise only from tariffs and tend to be highly sensitive to changes in prices since they depend on the value of net trades. These taxes are non-distorting, do not alter relative prices of outputs, and have no effect on the equilibrium solution produced by the model.

11. In our model revenue and quota rents are separately identified, since for developed countries revenues are positive and quota rents are zero, and for developing countries the opposite is true. 
12. In using this data we assume that all bilateral quotas were fully binding in the year in question. Whether textile quotas are or are not binding has been a source of controversy for some time. For some exporting countries not all the allocated (category-specific) quotas are fully utilized in any given year (see GATT (1984) and USITC (1987)). Thus it appears, at first sight, that the cost to the U.S. of imposing these restraints may be overestimated by the model. However, there are many reasons why data for export countries can seem to indicate non-binding quotas and yet in fact be binding. Quotas assigned to firms within an exporting country may not be fully utilized due to capacity constraints within firms and the unwillingness of firms to reassign or reallocate quota (or sell if there are legal markets) for fear of losing their quota allocation in future years. Other reasons can 1 ie in the way quota is allocated among importers. Textile quotas in the EEC, for instance, are often allocated between importing countries on the basis of historical market shares with no trading of quota across countries, so that quotas for, say, coats can be binding in Northern Europe but not in Southern Europe. Also sub-aggregate quotas, say for types of shirts, may be greater than an aggregate quota for shirts and hence not appear to be binding at subaggregate level while be binding at agregate level.

13. We were unable to obtain production data for some of the developing countries. In these cases trade data, along with estimates of mill consumption to export ratios obtained from FAO (1985) were used to calculate the value of production of each of the fourteen product categories in each country. 
14. The quota price data that exists is also heavily contaminated by the complexities of quota allocation schemes within countries. Thus a firm which openly and repeatedly sells quota, risks losing some or all of its quota allocation in future years. There is even the possibility of firms producing where their cost of production is above the import price in the consuming market to keep quota in future years. Quota price data also reveals wide fluctuations on a month by month basis (see Morke (1984) and Hamilton (1986)) in part because of the fashion component of textiles trade and the need to maintain flexibility to enter various product markets quickly to exploit emerging trends.

15. Tariffs on U.S. imports of textiles and apparel also enter this calculation, and these are obtained from GATT (1984).

16. The bilateral agreements in the U.S. invole comprehensive product coverage, which divides all the MFA products into 109 categories.

17. Hamilton (1988) analyzes these differences between Hong Kong, Taiwan, and South Korea and concludes they are small and can be ignored. Here, with 35 supplying countries, these factors become considerably more important.

18. Arithmetic average of all supply prices within the category.

19. The reason for making this assumption is because there are currently no estimates of import or export demand elasticities for the developing countries from which implied transformation and substitution elasticities can be calculated.

20. We assume conmon values between nests. 
21. Hufbauer et al. (1986) believe a conservative estimate of import elasticity of demand for imported textiles and apparel in the U.S. to be about -1.8 . We estimate import elasticity of demand in the U.S. at -8.9 .

22. Welfare estimates under Hicksian equivalent and compensating measures are very close, and so only EVs are reported.

23. In making this calculation, data on total manufacturing output by country are taken from the same sources as production data. However, data was unavailable for some of the developing countries. In these cases production data, along with estimates of the share of textiles and clothing in manufacturing production from GATT (1984) were used to calculate the value of total manufacturing production in each country.

24. There is some bias in making this comparison since in Case 1 of Table 5 all developed country bilateral quotas and tariffs are eliminated, whereas in Case 1 of Table 9 only bilateral quotas and tariffs in the U.S. are removed. Thus, not only are we capturing the trade diversion effects but also the effects of abolishing textile and apparel protection in Canada and the EEC, as well as in the U.S. Therefore, the comparison should be interpreted with caution. 


\section{Bibliography}

Baldwin, R.E. (1982) The Inefficacy of Trade Policy. Essays in International Finance. Princeton, New Jersey: Princeton University Press.

Cline, W.R. (1987) The Future of World Trade in Textiles and Apparel. Washington: Institute for International Economics.

Europa. The Europa Yearbook 1987: A Wurld Survey, Vols. I and II. Europa Publications Ltd.

European Conmission (1987). Eurostat. Catalogue reference 1520 .

Falvey, R. (1979) "The Composition of Trade Within Import Restricted Product Categories". Journal of Political Economy 87: 1105-1114.

Food and Agricultural Organization of the United Nations (1985) World Apparel Fibre Consumption Survey. FAO.

GATT. (1984) Textiles and Clothing in the World Economy. Background study prepared by the GATT Secretariat to assist work undertaken by the contracting Parties in pursuance of the Decision on Textiles and Clothing taken at the Nuvember 1982 ministerial meeting. Geneva: GATT. Greenaway, D. (1985) "Some Estimates of the Costs of Protection in Two Import Sensitive Sectors in the U.K." Draft of a paper presented at the European Trade Policies and the South Conference, the Hague, September 13 and 14.

Hamilton, c. (1986) "An Assessment of Voluntacy Restraints on Hong Kong Exports to Europe and USA". In Economica 53 (August). . (1988) "Restrictiveness and International Transmission of the "New" Protectionism". In Issues in US-EC Trade Relations. Edited by R. Baldwin, C. Hamilton, and A. Sapir. National Bureau of Economic Research and University of Chicago Press. 
Hufbauer, G.C., D.T. Berliner and K.A. Elliont (1986) Trade Protection in the United States: 31 Case Studies. Washington: Institute for International Economics.

Jenkins, G.P. (1980) Costs and Consequences of the New Protectionism: The Case of Canada's Clothing Sector. Ottawa: North-South Institute. Mansur, A. and J. Whalley (1984) "Numerical Specification of Applied General Equilibrium Models: Estimation, Calibration and Data". In Applied General Equilibrium Analysis. Edited by H. Scarf and J. Shoven. Cambridge: Cambridge University Press.

Morkre, M.E. (1984) Import Quotas on Textiles: The Welfare Effects of United States Restrictions on Hong Kong. Bureau of Economics Staff Report to the Federal Trade Commission. Washington, D.C.: U.S. Government Printing office.

Morkre, M.E. and D.G. Tarr (1980) The Effects of Restrictions on United States Imports: Five Case Studies and Theory. Staff Report to the Federal Trade Commission, Washington, DC: Government Printing office. OECD (1985) Costs and Benefits of Protection. Paris. Piggott, J. and J. Whalley (1985) U.K. Tax Policy and Applied General

Equilibrium Analysis. Cambridge: Cambridge University Press. Silberston, Z.A. (1984) The Multi-Fibre Arrangement and the UX Economy. London: HMSO.

Stern, R.M., J. Francis, and B. Schumacher (1976) Price Elasticities in International Trade: An Annotated Bibliography. London: Macmillan for the Trade Policy Research Centre.

United Nations (1986) Industrial Statistics Yearbook 1984. Vol. I: General Industrial Statistics. New York. United Nations Industrial Development Organization (UNIDO) (1985). Handbook of Industrial statistics 1984. New York. 
U.S. Department of Commerce. Office of Textiles and Apparel (June 1987a)

U.S. General Imports of Cotton Manufacturers Origin (TQ 2730 ). - (June 1987b) U.S. General Imports of Wool Manufacturers

(TQ 2740).

(June 1987c). U.S. General Imports of Man-Made Fibre

Manufacturers (TQ 2760).

- Bureau of Industrial Economics (1987d) U.S. Industrial Outlook.

Washington.

- (1985) U.S. Production, Imports and Import/Production Ratios for

Cotton, Wool and Man-Hade Fiber Textiles and Apparel.

U.S. International Trade Commission. (1987) U.S. Imports of Textiles and

Apparel Under the Multifiber Arrangement: Statistical Report through

1986. USITC Publication, 1986.

Whalley, J. (1985) Trade Liberalization Anong Major World Trading Areas, Cambridge: MIT Press.

World Bank. (1986) World Development Report 1986. New York: Oxford University Press. 